\title{
Prevalence of Alcohol Consumption and Knowledge About Alcohol at Bhimtar, Sindhupalchowk
}

\author{
Naresh Manandhar, ${ }^{1}$ Marina Vaidya Shrestha, ${ }^{1}$ Sunil Kumar Joshi ${ }^{1}$ \\ 'Department of Community Medicine, Kathmandu Medical College, Sinamangal, Kathmandu, Nepal.
}

Introduction: Alcohol causes several health problems, economic and social consequences across the world. Nepal is a multicultural and multi-ethnic country with an ambivalent regarding alcohol use according to social, religious and cultural values. Alcohol use is very common and easily available everywhere in Nepal. Objective of study is to find the prevalence of alcohol consumption and knowledge of alcohol among people at Bhimtar.

Methods: A cross sectional study was conducted on a total of 369 households, age above 20 years of Bhimtar, Sindhupalchowk district on November 2016. Total 41 households were selected using cluster sampling from all nine wards of Bhimtar village development committee.

Results: The prevalence of alcohol consumption was 232 (62.9\%) in which 144 (77.4\%) of males and $88(48.1 \%)$ of females. There was 3.3 times more chance of consuming alcohol in male than female. Majority 137 (37\%) consumed Raksi followed by Jaand/Chhyang 115 (31.3\% ) and mix 97 (26.4\%). On knowledge of alcohol consumption, 280 (75.9\%) and 288 (78.0\%) of current drinker opined that it would effects own health and on the family respectively. After drinking alcohol 118 (31.9\%) felt it relieved tiredness followed by felt better 103 (28\%) and reduced stress 70 (18.9\%). It affects heart and damage liver said by $72(19.4 \%)$ and 59 (16\%) respectively. There were family conflict after drinking alcohol replied by 132 (35.8\%). They have good knowledge about the affect of alcohol on pregnant women. Only $50(13.5 \%)$ of respondent expressed that it can be given to pregnant women.

Conclusions: The prevalence of alcohol consumption was very high. There is markedly differed in alcohol consumption by sex. It is affecting their health and family. Consumption of alcohol is financial burden and makes conflict in the family, which will also make psychological affect on their children. There is significant difference in knowledge of harm on alcohol consumption by education status. It is essential to plan and develop a specific health education program among these at-risk populations for prevention of alcohol consumption.

Keywords: current drinker; economic burden; ever drinker; family conflict; initiation.

\section{INTRODUCTION}

Alcohol causes several health economic and social consequences across the world. ${ }^{1}$ Alcohol is a psychoactive substance with dependence-producing properties that has been widely used. ${ }^{2}$ A survey found that $8,974(67.5 \%)$ respondents have consumed alcohol in Nepal. ${ }^{3}$ The prevalence of alcohol dependence was found to be 2344 (25.8\%) which increased with age to peak in the age group 45-54 years and was more than twice as common in men as in women. ${ }^{4}$

Current drinkers were found 168 (39.81\%) at Kathmandu valley in 2016 and male were more than

Correspondence: Dr. Naresh Manandhar, Department of Community Medicine, Kathmandu Medical College, Sinamangal, Kathmandu, Nepal. Email: nareshsayami@yahoo.com, Phone: +977. 9841500281 
the female on alcohol drink. ${ }^{5}$ Youth who start drinking before age 15 years are six times more likely to develop alcohol dependence than who begin drinking after 20 years. ${ }^{6}$ Production, sale, and consumption of alcohol are ever on the increase. ${ }^{7}$ Alcohol adversely affects the fetus when pregnant women drink. ${ }^{8}$

Objective of study is to find the prevalence of alcohol consumption and knowledge of alcohol in Bhimtar, Sindhupalchowk.

\section{METHODS}

A cross sectional descriptive study was conducted at Bhimtar, Sindhupalchowk district on November 2016. Ethical approval was taken from IRC of Kathmandu Medical College. Written consent was taken from each respondent and confidentiality of information of the respondents was maintained. The information they provided were used only for research purpose. Respondents were permanent resident of the Sindhupalchowk who were willing to participate and present during the study period were included in the study. Only one respondent was taken from each household.
$\mathrm{n}=\frac{\mathrm{Z}^{2} \mathrm{pq}}{\mathrm{e}^{2}}$

Where $\mathrm{n}$ is sample size,

p- prevalence of alcohol consumption $=39.81 \%$

$q$ - prevalence of non alcohol consumption $=(100-p)$

$=60.19 \%$

$Z=1.96$ at $95 \%$ confidence interval

e- allowable error $(5 \%)$

$\mathrm{n}=\frac{\left.(1.96)^{2} \times 39.81 \times 60.19\right)}{5^{2}}=369$

Total 41 Households were selected using cluster sampling from all nine wards of Bhimtar village development committee.

Pre-designed and structured questionnaire was used to collect the data by interview method. Data were analyzed by using SPSS version 22 .

\section{RESULTS}

The mean age of respondent was 40.67 years with 16.6 years of Standard deviation. Of the 369 study population, 186 (50.4\%) were male and 183 (49.6\%) were female.

\begin{tabular}{|c|c|c|c|c|c|c|}
\hline & $\begin{array}{l}\text { Variable } \\
\text { Yes (\%) }\end{array}$ & $\begin{array}{r}\text { Currently co } \\
\text { No (\%) }\end{array}$ & ling alcohol & $P$ value & $\begin{array}{l}\text { Odds } \\
\text { ratio }\end{array}$ & $95 \% \mathrm{Cl}$ \\
\hline \multirow{5}{*}{$\begin{array}{l}\text { Age Group } \\
\text { (in years) }\end{array}$} & $20-30$ & 61 (49.6) & $62(50.4)$ & 0.026 & 0.46 & $0.23-0.91$ \\
\hline & $30-40$ & 57 (67.9) & $27(32.1)$ & 0.008 & 0.99 & $0.47-2.08$ \\
\hline & $40-50$ & 41 (69.5) & $18(30.5)$ & 0.858 & 1.07 & $0.48-2.39$ \\
\hline & $50-60$ & $37(74.0)$ & $13(26.0)$ & 0.49 & 1.34 & $0.57-3.16$ \\
\hline & $>60$ & 36 (67.9) & $17(32.1)$ & - & - & Ref. \\
\hline \multirow{2}{*}{ Sex } & Male & $144(77.4)$ & $42(22.6)$ & $<0.001$ & 3.33 & $2.36-5.80$ \\
\hline & Female & $88(48.1)$ & 95 (51.9) & - & - & Ref. \\
\hline \multirow{6}{*}{ Occupation } & Farmer & 161 (66.5) & 81 (33.5) & 0.804 & 1042 & $0.60-3.33$ \\
\hline & Labour & $13(54.2)$ & $11(45.8)$ & 0.771 & 0.84 & $0.26-2.64$ \\
\hline & Business & $16(55.2)$ & $13(44.8)$ & 0.81 & 0.88 & $0.29-2.62$ \\
\hline & Housewife & $13(48.1)$ & $14(51.9)$ & 0.467 & 0.66 & $0.21-2.01$ \\
\hline & Unemployed & $15(65.2)$ & $8(34.8)$ & 0.62 & 1.34 & $0.41-4.36$ \\
\hline & Others & $14(58.3)$ & $10(41.7)$ & - & - & Ref. \\
\hline \multirow{3}{*}{ Marital status } & Married & $194(64.9)$ & $105(35.1)$ & 0.714 & 1.16 & $0.51-2.66$ \\
\hline & Unmarried & $22(50.0)$ & $22(50.0)$ & 0.93 & 0.62 & $0.23-1.67$ \\
\hline & Others & $16(61.5)$ & $10(38.5)$ & - & - & Ref. \\
\hline
\end{tabular}


The majorities $123(33.3 \%)$ were in age group $20-30$ years. Total of $84(22.8 \%)$ were in $30-40$ years of age. Odds ratios increased from 0.46 to 1.34 for age group 20-30 to 50-60 respectively. The prevalence of alcohol consumption was $232(62.9 \%)$ of which 144 (77.4\%) among males and 88 (48.1\%) among females. There is significant difference in alcohol consumption by sex and there was 3.3 times more chance of consuming alcohol in male than female. Respondents were asked about their main occupation, 242 (65.6\%) of them were farmer, $29(7.9 \%)$ were in business. Majority of the respondents $299(81 \%)$ were married (Table 1).

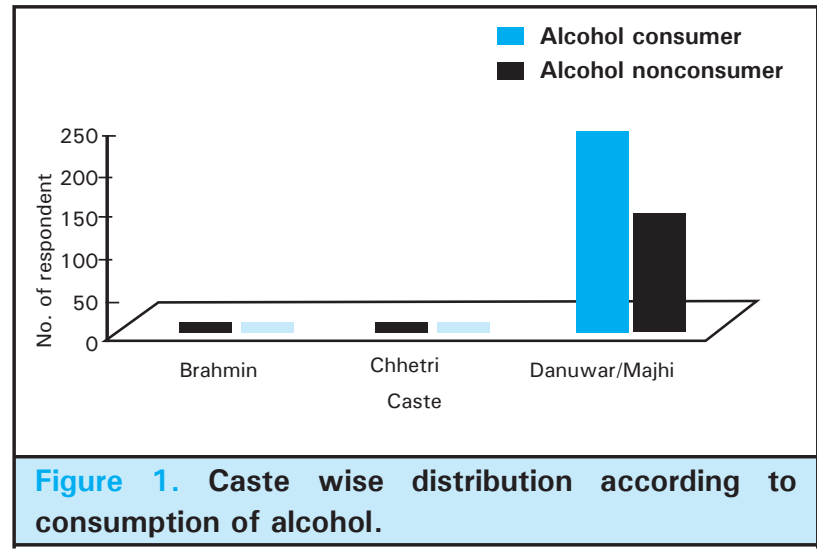

Maximum 257 (96.7\%) of study population were Danuwar/Majhi ethnic group (Figure 1).

\begin{tabular}{|c|c|c|c|c|c|}
\hline \multirow[b]{2}{*}{ Education Status } & \multicolumn{2}{|c|}{ Currently consuming alcohol } & \multirow[b]{2}{*}{$P$ value } & \multirow[b]{2}{*}{ Odds ratio } & \multirow[b]{2}{*}{$95 \% \mathrm{Cl}$} \\
\hline & Yes (\%) & No (\%) & & & \\
\hline Illiterate & $144(67.6)$ & $69(32.4)$ & 0.106 & 2.38 & $0.83-6.84$ \\
\hline Primary & $50(71.4)$ & $20(28.6)$ & 0.700 & 2.85 & $0.91-8.92$ \\
\hline Secondary & $23(46.0)$ & $27(54.0)$ & 0.963 & 0.96 & $0.30-3.09$ \\
\hline Higher Secondary & $8(38.1)$ & $13(61.9)$ & 0.607 & 0.70 & $0.18-2.69$ \\
\hline Bachelor and above & 7 (46.7) & 8 (53.3) & - & - & Ref. \\
\hline
\end{tabular}

\begin{tabular}{|c|c|c|c|c|}
\hline & Statement & $\begin{array}{r}\text { Illiterate/ } \\
\text { Primary n (\%) }\end{array}$ & $\begin{array}{r}\text { Secondary and } \\
\text { above n (\%) }\end{array}$ & $P$ value \\
\hline Alcohol consumption affect's own health & $\begin{array}{l}\text { Yes } \\
\text { No }\end{array}$ & $\begin{array}{r}198(70.0) \\
85(30.0)\end{array}$ & $\begin{array}{r}82(95.3) \\
4(4.7)\end{array}$ & $<0.001$ \\
\hline Effect on the family by alcohol consumption & $\begin{array}{r}\text { Yes } \\
\text { No }\end{array}$ & $\begin{array}{r}214(75.6) \\
69(24.4)\end{array}$ & $\begin{array}{l}74(86.0) \\
12(14.0)\end{array}$ & 0.041 \\
\hline Alcohol can be given during pregnancy & $\begin{array}{r}\text { Yes } \\
\text { No }\end{array}$ & $\begin{array}{r}42(14.8) \\
241(85.2)\end{array}$ & $\begin{array}{r}8(9.3) \\
78(90.7)\end{array}$ & 0.189 \\
\hline Drink huge amounts at once & $\begin{array}{r}\text { Yes } \\
\text { No }\end{array}$ & $\begin{array}{r}18(9.8) \\
165(90.2)\end{array}$ & $\begin{array}{r}0(0.0) \\
51(100.0)\end{array}$ & 0.020 \\
\hline Drink more now than when first started & $\begin{array}{r}\text { Yes } \\
\text { No }\end{array}$ & $\begin{array}{l}113(52.8) \\
101(47.2)\end{array}$ & $\begin{array}{l}14(27.5) \\
37(72.5)\end{array}$ & 0.001 \\
\hline Drinking ever cause problems at home or work & $\begin{array}{r}\text { Yes } \\
\text { No }\end{array}$ & $\begin{array}{r}47(22.0) \\
167(78.0)\end{array}$ & $\begin{array}{r}5(9.8) \\
46(90.2)\end{array}$ & 0.049 \\
\hline Ever felt your needed a drink as eye opener & $\begin{array}{r}\text { Yes } \\
\text { No }\end{array}$ & $\begin{array}{r}33(15.4) \\
181(84.6)\end{array}$ & $\begin{array}{r}7(13.7) \\
44(86.3)\end{array}$ & 0.761 \\
\hline Ever felt you needed to cut down your drinking & $\begin{array}{r}\text { Yes } \\
\text { No }\end{array}$ & $\begin{array}{r}123(57.5) \\
91(42.5)\end{array}$ & $\begin{array}{l}33(64.7) \\
18(35.3)\end{array}$ & 0.364 \\
\hline Felt annoyed by people criticizing your drinking & $\begin{array}{r}\text { Yes } \\
\text { No }\end{array}$ & $\begin{array}{r}69(32.2) \\
145(67.8)\end{array}$ & $\begin{array}{r}8(15.7) \\
43(84.3)\end{array}$ & 0.019 \\
\hline Felt guilty about drinking & $\begin{array}{r}\text { Yes } \\
\text { No }\end{array}$ & $\begin{array}{l}107(50.7) \\
104(49.3)\end{array}$ & $\begin{array}{l}23(45.1) \\
28(54.9)\end{array}$ & 0.472 \\
\hline
\end{tabular}


Majority of the respondents 209 (57.7\%) were illiterate and out of them $144(67.7 \%)$ consumed alcohol. There is more than two times chances of consuming alcohol with the low level of education (illiterate and primary) compared to higher level of education (Table 2).

In Nepal, the legal age for alcohol drinking is 18 years. This study showed that majority of the respondents initiated drinking alcohol before the legal age of drinking. The mean age of initiation of alcohol consumption was 16.7 years with standard deviation of 5.2 years. Among those who consumed alcohol, $72(31.0 \%)$ consumed daily and mostly $118(50.9 \%)$ in the evening. The study found that majority $206(88.9 \%)$ consumed alcohol at home.

When the effect of alcohol consumption on health were asked to respondents, 198 (70.0 \%) and 82 (95.3\%) of illiterate/ primary and secondary and above opined that it would effects own health respectively which is significant difference. There will be effect on the family by alcohol consumption positively replied by $214(75.6 \%)$ and $74(86.0 \%)$ of illiterate/ primary and secondary and above respectively (Table 3 ).

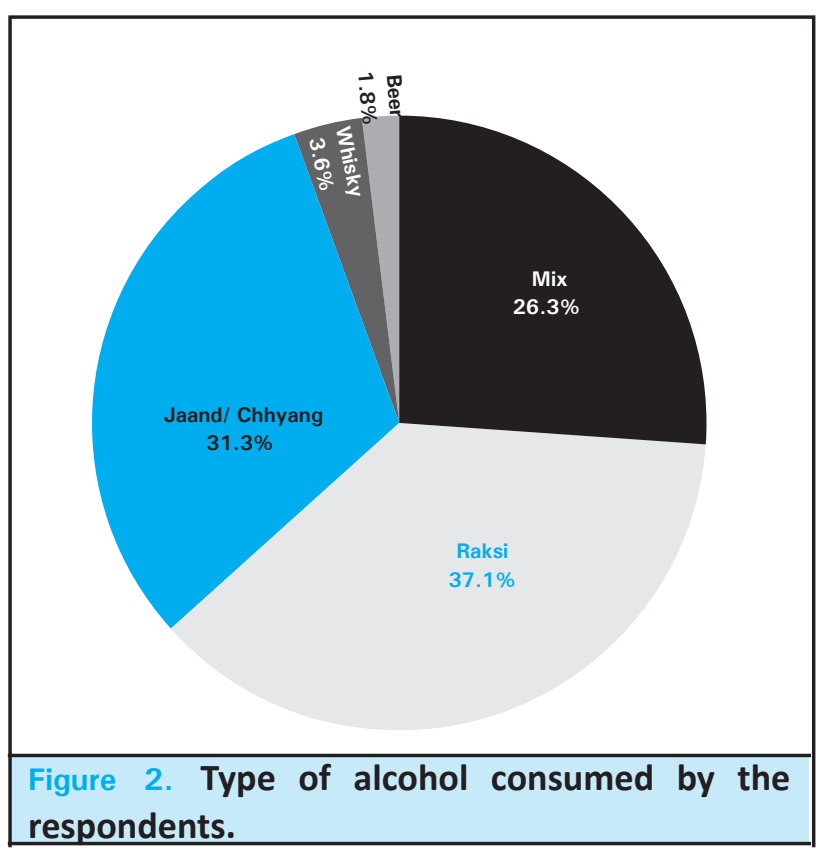

Majority of respondent consumed local or homemade alcohol, 86 (37.1\%) consumed Raksi and 73 (31.3\%) consumed Jaand/ Chhang (Figure 2).

\section{DISCUSSION}

The mean age of initiating drinking alcohol was found to be 16.7 years. The prevalence of alcohol consumption was $62.9 \%$ of which $77.4 \%$ among males and $48.1 \%$ among females. Among the study population, $62.8 \%$ were current drinker and $73.8 \%$ were ever consumed of alcohol. This result is similar to study conducted by Maharjan et al at Bhaktpur in 2017 where it was $67.2 \% .^{9}$ "Adolescents and Youth Survey 2011" conducted by Ministry of Health and Population revealed that $18 \%$ of adolescents and youth reported having ever used alcohol. ${ }^{7}$ In contrast to this study, result obtained from the study conducted on NCDs risk factors showed that $12.6 \%$ of age $15-29$ year old respondents were current drinkers. ${ }^{10}$ In the present study, odds ratio was seen to increase from 0.46 to 1.34 for age group 2030 and 50-60 respectively. This may be due to cultural practice in that particular ethnic group. The prevalence of alcohol consumption was $48.1 \%$ among female in present study which is higher than $16.6 \%$ the findings of study conducted by Niraula et al at Sunsari. ${ }^{11}$ This marked difference in prevalence may be due to study area in the present study high majority of ethnic groups Majhi/ Danuwar where alcohol is used traditionally. In the present study, the mean age of initiating drinking alcohol was found to be 16.7 years. This result was consistent with studies conducted by Khanal $\mathrm{P},{ }^{12}$ Thapa $\mathrm{P}^{5}$ and Maharjan $\mathrm{PL}^{9}$ where mean age of first exposure was 17.94 years, 17 years and 17 years respectively. In present study half of current drinkers drank at evening which is consistent with the result of Thapa $P$ where it was $45.24 \% .{ }^{5}$ In the present study, one third of the respondents $(31 \%)$ were found to drink daily. In contrast to this result, study conducted by Thapa $\mathrm{P}^{5}$ showed that $(13.1 \%)$ the respondents consumed alcohol daily and study by Dhital $\mathrm{R}$ reported only $11 \%$ consumed daily. ${ }^{13}$ In this study, most of the respondents (37\%) consumed Raksi. This finding was remarkably higher than finding of Thapa $\mathrm{P}$ where it was $13.69 \% .^{5}$

The present study revealed that $26.3 \%$ of respondent consumed mix alcohol which was higher than the finding of Maharjan $\mathrm{PL}^{9}$ where it was $19.4 \%$ and lower than finding of Thapa $\mathrm{P}$ where it was $30.36 \% .^{5}$

When the effect of alcohol consumption on health were asked to respondents, 198 (70.0 \%) and 82 (95.3\%) of illiterate/ primary and secondary and above opined that it would affects own health respectively which is significant difference $(P$ value $<0.001)$. There will be effect on the family by alcohol consumption positively replied by $214(75.6 \%)$ and $74(86.0 \%)$ of illiterate/ primary and secondary and above respectively. There is significant difference in knowledge of harm on alcohol consumption by education status ( $P$ value $<0.05$ ).

Limitations of present study were larger sample size and different community participants will give clearer picture. 


\section{CONCLUSIONS}

The prevalence of current alcohol consumption was very high when compared to study conducted on STEPS Survey Nepal 2013. Gender wise there is markedly differed in alcohol consumption. It is affecting their health and family. Consumption of alcohol is financial burden and makes conflict in the family, which gives psychological impact on their children. There is significant difference in knowledge of harm on alcohol consumption by education status. It is essential to plan and develop a specific health education program for prevention of alcohol consumption in high risk populations.

\section{ACKNOWLEDGEMENTS}

Authors would like to thank all the participants for their valuable information and III MBBS (1 $7^{\text {th }}$ Batch) students for helping in data collection. Authors also thank Dr. Komal Thapa, chairman of Indrawati Community Hospital, Sipaghat for helping to conduct this research.

Conflict of Interest: None.

\section{REFERENCES}

1. World Health Organization: Global status report on alcohol and health. In Geneva, Switzerland: The World Health Organization. 2011:1-85. [Full Text]

2. World Health Organization: Global status report on alcohol and health. In Geneva, Switzerland: The World Health Organization. 2014:1-94. [Full Text]

3. Ministry of Health and Population Nepal Adolescents and Youth Survey. Kathmandu, Nepal: Ministry of Health and Population. 2011. 1-55. [Full Text]

4. Jhingan HP, Shyangwa Pramod, Sharma Avneet, Prasad KMR, and Khandelwal SK. Prevalence of alcohol dependence in a town in Nepal as assessed by the CAGE questionnaire. Addiction: Society for the study of addiction. March 2003;98(3):339-43. [uuMed | Full Text]

5. Thapa P, Mishra S, Pandey A, Belbase P, Acharya C, et al. Prevalence and Predictors of Alcohol Consumption among the Squatter of Kathmandu Valley. Journal of Nepal Health Research Council. 2016;14:18-26. [Full Text]

6. Centers for Disease Control and Prevention. Fact Sheets-Underage Drinking. 2015. [Full Text]

7. Ministry of Health and Population. Nepal Adolescents and Youth Survey. Ministry of Health and Population, Kathmandu, Nepal.2016.1-79. [Full Text]
8. Beecroft J, Kemp A, Lassila S, Sheedy D, Ward E. The Biochemical and pathophysilogical effects of alcohol consumption: Christian Spiritual and Science. 2010;8(1):3. [Full Text]

9. Maharjan PL, Magar KT: Prevalence of Alcohol Consumption and Factors Associated with the Alcohol Use among the Youth of Suryabinayak Municipality, Bhaktapur. Journal of Pharmaceuticals and Care Health System.2017;4:168. [ [Full Text]

10. Nepal Health Research Council (NHRC), World Health Organization (WHO): Non Communicable Diseases Risk Factors: STEPS Survey Nepal. MoHP.Kathmandu, Nepal. 2013. [Full Text]

11. Niraula, SR, Shyangwa, PM; Jha, N; Paudel, R K; Pokharel, P. K:Alcohol use among women in a town of eastern, Nepal. Journal of the Nepal Medical Association. Sep/Oct 2004;43(155):244-9. [ Full Text]

12. Khanal P, Ghimire RH, Gautam B, Dhungana SK, Parajuli P, Jaiswal AK, Khanal B. Substance use among medical students in Kathmandu valley. JNMA Journal of Nepal Medical Association. 2010 Oct-Dec; 50(180):267-72. [PubMed]

13. Dhital R. Alcohol and young people in Nepal. The Globe. 2001;4:21-25. [Full Text] 